\title{
PREVALENSI KUALITAS TIDUR KELUARGA DI RUANG RAWAT INAP RS IZZA KARAWANG DI MASA PANDEMI COVID- 19
}

\section{Prevalence Of Sleep Quality Family Member In IZZA Karawang Hospital Inpatient Rooms During The Covid - 19 Pandemic}

\section{Zevi Agus Mulyana ${ }^{\text {* }}$ \\ Amzal Mortin Andas ${ }^{2}$}

Puji Astuti ${ }^{3}$

\author{
1,2,3 Sekolah Tinggi Kesehatan \\ Bani Saleh, Bekasi, Jawa Barat, \\ Indonesia
}

*email:

Andazmortin.a@gmail.com

Kata Kunci:

Covid-19

Keluarga pasien

Kualitas tidur

\section{Keywords:}

Covid-19

Patient's Family

Sleep Quality

\begin{abstract}
Abstrak
Latar Belakang

Keluarga pendamping pasien yang dirawat inap berisiko mengalami kualitas tidur yang buruk. Dampak kualitas tidur yang buruk dapat mempengaruhi mood, komunikasi yang tidak efektif dengan dokter atau perawat, dan mengganggu kemampuan mengambil keputusan dan perawatan. Tujuan penelitian untuk mengetahui prevalensi tingkat kualitas tidur keluarga di ruang rawat inap selama masa pandemi.
\end{abstract}

\section{Metode}

Desain penelitian ini adalah deskriptif analitik dengan pendekatan cross sectional. Populasi penelitian adalah seluruh keluarga pasien yang dirawat di ruang rawat inap pada masa pandemi, menggunakan teknik consecutive sampling dengan sampel sebanyak 53 responden. Peneliti menjaga kerahasiaan, memberikan keadilan dan menjelaskan tujuan dan manfaat penelitian kepada responden. Penelitian ini menggunakan analisis univariat.

Hasil

Hasilnya mayoritas yang mengalami kualitas tidur cukup 53 responden $(53,2 \%)$, kualitas buruk 31 responden (32,3\%), dan kualitas baik 12 responden (I2,5\%).

\section{Kesimpulan}

Kesimpulan menunjukkan bahwa keluarga pasien mengalami kualitas tidur yang cukup. Peneliti selanjutnya diharapkan dapat meneliti faktor-faktor yang berhubungan dengan kualitas tidur keluarga di berbagai tempat seperti ruang rawat inap rumah sakit rujukan covid atau ruang ICU.

\begin{abstract}
Background of Study: The accompanying family of patients who are hospitalized are at risk of experiencing poor sleep quality. The impact of poor sleep quality can affect mood, ineffective communication with doctors or nurses, and interfere with the ability to make decisions and care. The purpose of the study was to determine the prevalence of family sleep quality levels in inpatient rooms during the pandemic.

Methods : The design of this research is descriptive analytic with a cross sectional approach. The study population was the entire family of patients who were treated in an inpatient room during the pandemic, using a consecutive sampling technique with a sample of 53 respondents. Researchers maintain confidentiality, provide fairness and explain the purpose and benefits of research to respondents. This study used univariate analysis.
\end{abstract}

Results : The results were the majority who experienced adequate sleep quality 53 respondents (53.2\%), bad quality 31 respondents (32.3\%), and good quality 12 respondents (I2.5\%).

Conclusions : The conclusion shows that the patient's family experienced adequate sleep quality. Future researchers are expected to examine factors related to family sleep quality in different places such as the Intensive Care Unit (ICU). 


\section{PENDAHULUAN}

Kualitas tidur merupakan ukuran dimana seseorang itu dapat kemudahan dalam memulai tidur dan untuk mempertahankan tidur, kualitas tidur seseorang dapat digambarkan dengan lama waktu tidur, dan keluhankeluhan yang dirasakan saat tidur ataupun sehabis bangun tidur (Suastika, Jaya, and IGN 2020). Prevalensi gangguan tidur di dunia diperkirakan antara 5-15\% dan berkembang menjadi masalah insomnia kronik sekitar 31-75\%. Di Indonesia penelitian epidemiologi mengenai gangguan tidur masih sangat jarang, Penelitian oleh Nur aini et al melaporkan prevalensi gangguan tidur pada remaja di Indonesia adalah $38 \%$ untuk remaja di daerah urban dan $37,7 \%$ di daerah suburban, (Nur'aini et al. 2014).

Data global pada tanggal I4 Juli 202I terdapat 187.519.798 kasus COVID-19 yang dikonfirmasi dan 4.049.372 jiwa kematian, 3.400.884.367 dosis vaksin telah diberikan, Asia tenggara 36.196.974 kasus dan meninggal 516.608 jiwa, sedangkan di Indonesia dari 3 Januari 2020 - 14 Juli 202I, ada 2.615 .529 kasus terkonfirmasi COVID-19 dengan 68.219 kematian yang dilaporkan WHO Per I2 Juli 202I, total 52.286.047 dosis vaksin telah diberikan (World Health Organization 202I). I5 juli 202 I total terkonfirmasi covid-19 sebanyak 2,670.046, dirawat inap sebanyak 443,473 pasien dan sembuh 2.157.363 dan meninggal sebanyak 69.210. dan data di jawa barat terkonfirmasi covid-19 sebanyak 477.585 dan dalam perawatan I0I.742 dan sembuh sebanyak 368.94I, dan pasien meninggal 6.902 .

Studi telah mengidentifikasi kualitas tidur yang buruk sangat terkait dengan kemiskinan, pekerjaan, pendidikan dan status kesehatan. Beberapa faktor lain yaitu faktor lingkungan termasuk kebisingan, suhu ruangan, cahaya terang, sementara faktor psikologis misalnya kecemasan dan depresi (Suastika Anak Agung, Lesmana Cokorda, and IGN 2020). Dampak kurang tidur dapat mengganggu kemampuan mengambil keputusan dan merawat(Schmidt and Azoulay 2013) dan dapat mempengaruhi suasana hati dan komunikasi dengan baik dengan dokter atau perawat (Robert L, Huynh, and Giora 2017).

Dampak kualitas tidur yang buruk dapat dicegah dengan cara memberikan brosur informasi keluarga, konferensi keluarga rutin, putaran keluarga harian, informasi terstruktur, jam kunjungan tidak terbatas, pertemuan rutin perawat-keluarga-dokter, perawat spesialis perawatan keluarga, dan sebagainya mungkin terbukti efektif dalam mencegah sindrom keluarga perawatan pasca-intensif. (Schmidt and Azoulay 20I3).

Kualitas tidur yang baik ataupun buruk dapat kita ukur dengan menggunakan alat untuk mengukur tingkat kualitas tidur yaitu Sleep Quality Scale (SQS) Single Item, (Amzal Mortin Andas, Christantie Effendi, and Sri Setyarini 2020), dimana instrumen ini praktis jika pengukuran dilakukan pada interval yang sering, seperti dalam buku harian pasien yang diselesaikan setiap hari. Buku harian tidur adalah penilaian yang handal dan valid untuk menangkap hasil yang dilaporkan pasien dan mengurangi bias ingatan karena dikumpulkan setiap hari (Cappelleri et al. 2009). Hasil penelitian (Suastika Anak Agung et al. 2020) didapatkan bahwa 93,3\% pendamping pasien mengalami kualitas tidur yang buruk. Angka kejadian kualitas tidur cukup tinggi pada pendamping pasien yang dilaksanakan pada tahun 2019.

Kualitas tidur keluarga pasien rawat inap rumah sakit di Indonesia belum mendapatkan perhatian yang cukup. Berdasarkan hasil dari uraian di atas bahwasanya keluarga yang berada di Ruang Rawat Inap Rumah Sakit mengalami kualitas tidur yang buruk hingga sangat buruk. Maka dari itu, peneliti tertarik untuk melakukan penelitian tentang "Prevalensi Kualitas Tidur Keluarga di Ruang Rawat Inap Rumah Sakit IZZA Karawang Dimasa Pandemi COVID-19”.

\section{METODOLOGI}


Desain penelitian ini menggunakan deskriptif analitik dengan pendekatan cross- sectional. Penelitian ini dilaksanakan mulai bulan Juni - bulan Juli 2021 dan bertempat di Rumah Sakit Izza Cikampek. Populasi dalam penelitian ini adalah seluruh keluarga pasien yang dirawat diruang rawat inap masa pandemi COVID-19. Sampel diambil menggunakan tekhnik consekutive sampling berdasarkan kriteria inklusi yaitu keluarga inti atau keluarga dekat dari pasien, keluarga telah berada di ruang rawat inap selama 24 jam, minimal berumur 17 tahun, dan dapat berkomunikasi dengan baik dan dapat mengisi kuesioner, yang didapatkan sampel berjumlah 96 responden. Kriteria eklusi penelitian ini adalah keluarga pasien yang tidak dapat membaca dan menulis, dalam keadaan bingung dan tidak dapat mengekspresikan perasaannya, menolak menjadi responden.

Variabel pada penelitian ini adalah kualitas tidur, dan variabel berdasarkan karakteristik responden yaitu usia, jenis kelamin, pendidikan, pekerjaan, status hubungan serta riwayat penyakit. Instrumen yang digunakan dalam penelitian ini adalah kuesioner karaktreristik responden yang diisi menggunakan link google form dan kuesioner Sleep Quality Scale (SQS) Single Item yang diisi secara langsung oleh responden menggunakan hard copy. Analisis data menggunakan analisis univariat. Pengolahan data dilakukan dengan editing, coding, entry, tabulating, cleaning yang di olah melalui program software Statistical Product and Service Solution (SPSS).

\section{HASIL DAN PEMBAHASAN}

Tabel I. Distribusi Frekuensi Gambaran Karakteristik Responden Diruanng Rawat Inap Rumah Sakit Izza Cikampek

\begin{tabular}{|c|c|c|c|}
\hline \multirow[t]{2}{*}{ No } & \multirow[t]{2}{*}{$\begin{array}{l}\text { Karakteristik } \\
\text { Responden }\end{array}$} & \multicolumn{2}{|c|}{$\begin{array}{l}\text { Distribusi } \\
\text { Frekuensi } \\
\quad(n=97)\end{array}$} \\
\hline & & $\mathbf{F}$ & $\%$ \\
\hline \multirow[t]{7}{*}{ I } & Kategori Usia & & \\
\hline & $\begin{array}{l}\text { Remaja awal (I7-25 } \\
\text { tahun) }\end{array}$ & 22 & 22.9 \\
\hline & $\begin{array}{l}\text { Dewasa Awal (26- } \\
35 \text { tahun) }\end{array}$ & 24 & 25.0 \\
\hline & $\begin{array}{l}\text { Dewasa Akhir (36- } \\
45 \text { tahun) }\end{array}$ & 30 & 31.3 \\
\hline & $\begin{array}{l}\text { Lansia Awal (46-55 } \\
\text { tahun) }\end{array}$ & 15 & 15.6 \\
\hline & $\begin{array}{l}\text { Lansia Akhir (56-65 } \\
\text { tahun) }\end{array}$ & 5 & 5.2 \\
\hline & $\begin{array}{l}\text { Lansia } \\
\text { (>65 tahun) }\end{array}$ & 0 & 0 \\
\hline \multirow[t]{3}{*}{2} & Jenis Kelamin & & \\
\hline & Laki-laki & 45 & 46.9 \\
\hline & Perempuan & 51 & 53.1 \\
\hline \multirow[t]{6}{*}{3} & Pendidikan & & \\
\hline & Tidak sekolah & 2 & 2.1 \\
\hline & $\mathrm{SD} /$ sederajat & 20 & 20.8 \\
\hline & SMP/sederajat & 9 & 9.4 \\
\hline & SMA/sederajat & 52 & 54.2 \\
\hline & Perguruan tinggi & 13 & 13.5 \\
\hline \multirow[t]{3}{*}{4} & Pekerjaan & & \\
\hline & Tidak Bekerja & 39 & 40.6 \\
\hline & Bekerja & 57 & 59.4 \\
\hline \multirow[t]{3}{*}{5} & Status Hubungan & & \\
\hline & keluarga inti & 83 & 86.5 \\
\hline & keluarga besar & 13 & 13.5 \\
\hline \multirow[t]{4}{*}{6} & Riwayat Penyakit & & \\
\hline & $\mathrm{Ya}$ & 14 & 14.6 \\
\hline & Tidak & 82 & 85.4 \\
\hline & Total & 96 & 100 \\
\hline
\end{tabular}

Tabel I menunjukan hasil bahwa dari 96 responden, karakteristik usia responden di dominasi oleh kategori usia dewasa akhir (36-45 tahun) 30 responden (31,3\%), karakteristik jenis kelamin responden didominasi oleh jenis kelamin perempuan dengan jumlah $5 \mathrm{I}$ responden (53,I\%), karakteristik pendidikan responden di dominasi oleh yang pendidikan terakhirnya SMA/SMK/Sederajat dengan jumlah 52 responden (54,2\%), karakteristik pekerjaan responden sebagian besar yaitu bekerja dengan jumlah 57 responden $(59,4 \%)$, status hubungan responden mayoritas yaitu sebagai keluarga inti sebanyak 83 responden (86,5\%) 
dan mayoritas responden tidak memiliki riwayat penyakit sebanyak 82 responden $(85,4 \%)$.

Tabel 2. Distribusi Frekuensi Gambaran Kualitas Tidur Keluarga Di ruang Rawat Inap Rumah Sakit Izza Cikampek

\begin{tabular}{llcc}
\hline No & $\begin{array}{l}\text { Kualitas Tidur } \\
\text { Keluarga }\end{array}$ & N & $\%$ \\
\hline I & Buruk Sekali & 0 & 0,0 \\
2 & Buruk & 31 & 32.3 \\
3 & Cukup & 53 & 55.2 \\
4 & Baik & 12 & 12.5 \\
5 & Baik Sekali & 0 & 0,0 \\
\hline \multicolumn{2}{r}{ Jumlah } & 96 & 100.0 \\
\hline
\end{tabular}

Hasil analisa tabel 2 didapatkan bahwa kualitas tidur keluarga pasien mayoritas berada pada kualitas tidur cukup sebanyak 53 responden (53,2\%), yang mengalami kualitas tidur buruk sebanyak 31 responden (32,3\%), dan kualitas tidur baik sebanyak 12 responden (12,5\%). Pada hasil penelitian ini tidak ada responden yang mengalami kualitas tidur buruk sekali ataupun baik sekali.

Tabel 3. Prevalensi Kualitas tidur Keluarga berdasarkan karakteristik responden Di ruang Rawat Inap Rumah Sakit Izza Cikampek

\begin{tabular}{|c|c|c|c|c|c|c|c|c|}
\hline \multirow[t]{2}{*}{ Karakteristik Responden } & \multirow[t]{2}{*}{$\mathbf{F}$} & \multirow[t]{2}{*}{$\%$} & \multicolumn{6}{|c|}{ Kualitas Tidur Keluarga } \\
\hline & & & Buruk & $\%$ & cukup & $\%$ & Baik & $\%$ \\
\hline \multicolumn{9}{|l|}{ Kategori Usia } \\
\hline Remaja awal & 22 & 22.9 & 8 & 8,3 & 11 & 11,5 & 3 & 3,1 \\
\hline Dewasa Awal (26-35 tahun) & 24 & 25.0 & 6 & 6,3 & 13 & 13,5 & 5 & 5,2 \\
\hline Dewasa Akhir (36-45 tahun) & 30 & 31.3 & 12 & 12,5 & 15 & 15,6 & 3 & 3,1 \\
\hline Lansia Awal (46-55 tahun) & 15 & 15.6 & 4 & 4,2 & 11 & 11,5 & 0 & 0 \\
\hline Lansia Akhir (56-65 tahun) & 22 & 22.9 & 1 & 1.0 & 3 & 3.1 & 1 & 1.0 \\
\hline Manula (>65 tahun) & 0 & 0 & 0 & 0 & 0 & 0 & 0 & 0 \\
\hline \multicolumn{9}{|l|}{ Jenis Kelamin } \\
\hline Laki-laki & 45 & 46.9 & 13 & 13,5 & 27 & 28,1 & 5 & 5.2 \\
\hline Perempuan & 51 & 53.1 & 18 & 18.8 & 26 & 27.1 & 7 & 7.3 \\
\hline \multicolumn{9}{|l|}{$\overline{\text { Pendidikan }}$} \\
\hline Tidak sekolah & 2 & 2.1 & 0 & 0.0 & 1 & 1.0 & I & 1.0 \\
\hline SD/sederajat & 20 & 20.8 & 5 & 5.2 & 13 & 13.5 & 2 & 2.1 \\
\hline SMP/MTs/sederajat & 9 & 9.4 & 4 & 4.2 & 4 & 4.2 & 1 & 1.0 \\
\hline SMA/SMK/sederajat & 52 & 54.2 & 18 & 18.8 & 28 & 29.2 & 6 & 6.3 \\
\hline Perguruan tinggi & 13 & 13.5 & 4 & 4.2 & 7 & 7.3 & 2 & 2.1 \\
\hline \multicolumn{9}{|l|}{ Pekerjaan } \\
\hline Tidak Bekerja & 39 & 40.6 & 15 & 15.6 & 21 & 21.9 & 3 & 3.1 \\
\hline Bekerja & 57 & 59.4 & 16 & 16.7 & 32 & 33.3 & 9 & 9.4 \\
\hline \multicolumn{9}{|l|}{ Status Hubungan } \\
\hline keluarga inti & 83 & 86.5 & 26 & 27.1 & 47 & 49.0 & 10 & 10.4 \\
\hline keluarga besar & 13 & 13.5 & 5 & 5.2 & 6 & 6.3 & 2 & 2.1 \\
\hline \multicolumn{9}{|l|}{ Riwayat Penyakit } \\
\hline Ya & 14 & 14.6 & 2 & 2.1 & 9 & 9.4 & 3 & 3.1 \\
\hline Tidak & 82 & 85.4 & 29 & 30.2 & 44 & 45.8 & 9 & 9.4 \\
\hline TOTAL & 96 & 100 & $3 \mathbf{3}$ & 32.3 & 53 & 55.2 & 12 & 12.5 \\
\hline
\end{tabular}


Tabel 3 menunujukan bahwa pada kategori usia, mayoritas mengalami kualitas tidur cukup sebanyak 15 responden (15.6\%) pada dewasa akhir, hasil dari kategori jenis kelamin mayoritas mengalami kualitas tidur yang cukup laki-laki sebanyak 27 responden (28.1\%). Kategori pendidikan mayoritas responden berpendidikan SMA/SMK/Sederajat dan mengalami kualitas tidur yang cukup sebanyak 28 responden (29.2\%). Hasil dari kategori pekerjaan mayoritas yang mengalami kualitas cukup sebanyak 32 responden (33.3\%) dari responden yang bekerja. Hasil dari kategori status hubungan, sebagianbesar keluarga inti dan mengalami kualitas tidur cukup sebanyak 47 responden $(49,0 \%)$ Hasil kategori riwayat penyaki, mayoritas responden yang tidak memiliki riwayat penyakit mengalami kualitas tidur cukup sebanyak 44 responden (45.8\%) dan yang memiliki riwayat penyakit mayoritas mengalami kualitas tidur yang cukup sebanyak 9 responden (9\%).

\section{PEMBAHASAN}

Hasil penelitian menunjukan bahwa dari 96 responden pada penelitian ini sebagian besar responden berada pada kategori dewasa akhir dengan jumlah 30 responden $(31,2 \%)$. Sebagian besar responden yang mengalami kualitas tidur buruk pada keluarga pasien Diruang Rawat Inap Rumah Sakit Izza Cikampek di dominasi oleh kategori usia dewasa akhir dengan rentang usia 36-45 tahun sebanyak 12 responden (12,5\%), dan mayoritas responden yang mengalami kualitas tidur yang baik di dominasi oleh kategori usia dewasa awal (26-35 tahun) sebanyak 5 responden (5,2\%).

Penelitian ini sejalan dengan penelitian yang dilakukan oleh (Suastika et al. 2020) yang berjudul Prevalensi kualitas tidur pada pendamping pasien caregiver di Ruang Mawar RSUP Sanglah yang mendapatkan hasil bahwa mayoritas responden pada kategori usia dewasa akhir mengalami kualitas tidur yang buruk sebanyak 8 responden (80\%). Penelitian sebelumnya yang dilakukan oleh (Verceles et al. 2014) menunjukan hasil bahwa mayoritas responden dengan usia 46,I tahun mengalami kantuk berlebih saat siang hari ketika mendampingi pasien di rawat di rumah sakit sebanyak 38 responden di karenakan kualitas tidur yang kurang baik.

Seseorang mengalami penurunan pada fungsi organnya ketika memasuki masa tua yang mengakibatkan lansia rentan terhadap penyakit seperti nyeri sendi, osteoporosis, parkinson. Usia memiliki pengaruh terhadap kualitas tidur seseorang yang dikaitkan dengan penyakit yang dialami dan kesehatan yang buruk (Khasanah and Hidayati 20I2). Hal diatas didukung penelitian di Brazil bahwa lansia berusia 7079 tahun memiliki kualitas tidur buruk yang dikaitkan dengan penyakit somatik dan kesehatan yang buruk (Oliveira , 2010).

Sebagian besar responden berjenis kelamin perempuan dengan jumlah $5 \mathrm{I}$ responden $(53,1 \%)$. Sebagian besar responden yang mengalami kualitas tidur buruk pada keluarga pasien Diruang Rawat Inap Rumah Sakit Izza Cikampek di dominasi oleh responden berjenis kelamin perempuan sebanyak 18 responden $(18,8 \%)$.

Penelitian ini sejalan dengan penelitian yang dilakukan oleh (Suastika et al. 2020) yang berjudul Prevalensi kualitas tidur pada pendamping pasien (caregiver) di Ruang Mawar RSUP sanglah yang mendapatkan hasil bahwa mayoritas responden berjenis kelamin perempuan memiliki kualitas tidur yang buruk/tidak baik sebesar 14 responden (92,9\%). Namun dalam Penelitian (Baskara and Ropyanto 2017) menunjukan hasil bahwa mayoritas responden dalam penelitiannya berjenis kelamin perempuan sebanyak 134 responden dan didapatkan hasil bahwa rata-rata keluarga yang mendampingi pasien di rumah sakit mengalami kualitas tidur yang baik.

Perempuan memiliki kualitas tidur yang buruk disebabkan karena terjadi penurunan pada hormon progesteron dan estrogen yang mempunyai reseptor di hipotalamus, sehingga memiliki andil pada irama sirkadian dan pola tidur secara langsung. Kondisi 
psikologis, meningkatnya kecemasan, gelisah dan emosi sering tidak terkontrol pada wanita akibat penurunan hormon estrogen yang bisa menyebabkan gangguan tidur (Khasanah and Hidayati 20I2).

Berdasarkan pendapat peneliti, Perempuan akan sangat mudah merasakan cemas dan khawatir terhadap suatu hal, termasuk khawatir memikirkan pasien yang sakit. la akan selalu memikirkan hal tersebut, sehingga dapat membuat mereka sulit untuk beristirahat, dan menjadi gangguan dalam tidur. Sehingga rata-rata perempuan akan mengalami kualitas tidur yang buruk.

Sebagian besar responden berpendidikan SMA/SMK dengan jumlah 52 responden (54,2\%). Sebagian besar responden yang mengalami kualitas tidur buruk pada keluarga pasien Diruang Rawat Inap Rumah Sakit Izza Cikampek di dominasi oleh responden dengan pendidikan SMA/SMK sebanyak 18 responden (I8,8\%). Penelitian ini sejalan dengan penelitian yang dilakukan oleh (Suastika et al. 2020) yang berjudul Prevalensi kualitas tidur pada pendamping pasien (caregiver) di Ruang Mawar RSUP sanglah yang mendapatkan hasil bahwa mayoritas responden berpendidikan SMA/SMK memiliki kualitas tidur yang buruk/tidak baik sebesar 12 responden (92,3\%). Penelitian sebelumnya yang dilakukan oleh (Baskara and Ropyanto 2017) didapatkan hasil lebih dari separuh jumlah responden memiliki tingkat pendidikan SMA (65.6\%)

Pada penelitian (Baskara and Ropyanto 2017) anggota keluarga yang mendampingi pasien di rumah sakit mayoritas adalah bekerja sebanyak 96 responden. Penelitian ini sejalan dengan penelitian yang dilakukan oleh (Suastika et al. 2020) yang berjudul Prevalensi kualitas tidur pada pendamping pasien (caregiver) di Ruang Mawar RSUP sanglah yang mendapatkan hasil bahwa mayoritas responden yang bekerja memiliki kualitas tidur yang buruk/tidak baik sebesar 25 responden.

Kualitas tidur buruk pada malam hari yang dirasakan keluarga pasien dapat membuat kantuk yang berlebih pada sianghari sehingga keluarga akan mengalami gangguan aktivitas diantaranya aktivitas bekerja (Verceles et al., 2014).

Status hubungan responden sebagai keluarga inti berjumlah 83 responden (86,5\%) dengan rata-rata mengalami kualitas tidur cukup dengan jumlah 47 responden (49,0\%). Pada penelitian ini didapatkan hasil bahwa sebagian besar responden yang mengalami kualitas tidur buruk di dominasi oleh responden yang memiliki status hubungan keluarga inti dengan pasien sebanyak 26 responden (27,0\%).

Penelitian ini sejalan dengan penelitian (Suastika et al. 2020) mendapatkan hasil bahwa mayoritas responden atau pendamping pasien di rumah sakit termasuk keluarga inti sebanyak 21 responden (70,0\%). Penelitian sebelumnya oleh Day et al., (20/3) menunjukan hasil bahwa mayoritas anggota keluarga yang mendampingi pasien memiliki status hubungan anak yaitu sebanyak $43,6 \%$ dan rata-rata responden dalam penelitianini mengalami gangguan tidur .

Keluarga inti yang mendampingi pasien saat di rawat di rs diantaranya adalah ibu, ayah, suami, istri, kakak ataupun adik. Keluarga inti merupakan keluarga terdekat yang selalu berada di sisi kita. Sehingga dalam penelitian ini rata-rata pendamping pasien adalah keluarga inti. Ketika pasien sakit merekalah yang akan membantu mendampingi pasien dan membantu kebutuhan pasien selama sakit maupun selama dirawat. Peneliti berpendapat, Saat ada anggota keluarga yang sakit danharus di rawat inap tentunya seluruh anggota keluarga inti akan merasakan sedih, gellisah, cemas, khawatir. Mereka akan berusaha untuk menjaga dan mendampingi pasien sebaik mungkin bahkan ada yang harus berjaga semalaman. Perasaan yangtidak menentu yang dirasakan keluarga dapat membuat keluarga sulit tidur sehingga mengalami gangguan tidur, atau ketik aharus berjaga di rs fasilitas yang kurang baik, tempat tidur yang tidak memadai, yang membuat keluarga sulit untuk beristirahat itupun dapat membuat gangguan sulit tidur pada keluarga psien. Gangguan tiduratau kesulitan untuk tidurpada keluarga inti pasien membuat 
kualitas tidur dianta mereka menjadi tidak baik atau buruk.

Sesuai dengan penelitian yang dilakukan oleh Kristin F.M et al, (20I7), Dimana didapatkan bahwa sebagian besar pendamping pasien memiliki kualitas yang buruk sebesar $(72 \%) \mathrm{p}=0,00 \mathrm{I})$. Dikatakan bahwa keluarga inti merasakan langsung dampak akibat sakit yang diderita.

Responden tidak memiliki riwayat penyakit berjumlah 82 responden $(85,4 \%)$ dengan rata-rata mengalami kualitas tidur cukup dengan jumlah 44 responden $(45,8 \%)$. Pada penelitian ini didapatkan hasil bahwa sebagian besar responden yang mengalami kualitas tidur buruk pada keluarga pasien Diruang Rawat Inap Rumah Sakit Izza Cikampek di dominasi oleh responden yang tidak memiliki riwayat penyakit sebanyak 29 responden $(30,2 \%)$ dan sebagian kecil responden yang memiliki riwayat penyakit mengalami kualitas tidur buruk sebanyak 2,1\%. Penelitian (Harfiantoko and Kurnia 2013) menunjukan bahwa responden yang memiliki riiwayat penyakit hipertensi sedang dan berat rata-rata mengalami kualitas tidur yang buruk.

Seseorang yang memiliki riwayat penyakit dalam tubuhnya, tentu akan lebih mudah mengalami gangguan tidur yang menyebabkan kualitas tidur mereka menjadi kurang baik. Gangguan tidur tersebut dapat diakibatkan karena gejala-gejala penyakit yang dapat timbul kapanpun, termasuk ketika akan atau sedang tidur. Gejala yang dirasakan dapat berupa pusing, kesemutan, pegel pada bagian ekstermitas, dII . Penelitian (Suastika et al. 2020) menunjukan hasil bahwa Kualitas tidur pada responden dengan riwayat stroke memiliki kualitas tidur buruk yaitu 19 responden atau sebesar $100 \%$.

Mayoritas kualitas tidur keluarga pasien Diruang Rawat Inap Rumah Sakit Izza Cikampek Di Masa Pandemic Covid- 19 berada pada kualitas tidur cukup sebanyak 53 responden (53,2\%), di ikuti dengan responden yang mengalami kualitas tidur buruk sebanyak 31 responden $(32,3 \%)$, dan responden yang mengalami kualitas tidur baik sebanyak 12 responden (12,5\%). Pada hasil penelitian ini tidak ada responden yang mengalami kualitas tidur buruk sekali ataupun baik sekali.

Penelitian ini menunjukan bahwa prevalensi responden yang mengalami kualitas tidur buruk cukup tinggi yaitu sekitar 32,3\%. Penelitian ini sejalan dengan (Suastika et al. 2020) yang menunjukan bahwa angka kejadian kualitas tidur pada pendamping pasien tahun 2019 ditempat dilaksanakan penelitian ini cukup tinggi. Hasil penelitian ini didapatkan bahwa 93,3\% pendamping pasien mengalami kualitas tidur yang buruk. Penelitian (Day et al. 2013) mendapatkan hasil bahwa dari 94 responden, 66,0\% dilaporkan mengalami kesulitan tidur,43,5\% menggambarkan kualitas tidur buruk atau sangat buruk, dan hanya 15,1\% menggambarkan kualitas tidur baik atau sangat baik. Dalam studi oleh Van Horn dan Tesh, 70\% dari 50 anggota keluarga pasien ICU dewasa melaporkan kualitas tidur yang lebih buruk dibandingkan dengan tidur sebelum masuk ICU, dan $80 \%$ tidur kurang dari jumlah biasanya (Van Horn and Tesh 2000). Dalam studi oleh Halm dkk., 36\% dari 52 anggotakeluarga pasien ICU melaporkan kualitas tidur yang lebih buruk dan 44,8\% melaporkan jumlah tidur yang berkurang, dibandingkan dengan waktu sebelum masuk ICU (Halm et al. 1993).

Gangguan tidur yang dirasakan oleh anggota keluarga pasien di ruang rawat inap dapat di sebabkan karena keluarga merasa khawatir dan cemas terhadap kondisi pasien, keluarga tidak dapat beristirahat dengan tenang ketika mendampingi pasien di ruang rawat inap. Kebutuhan untuk tetap dekat dengan pasien menjadi alasan utama anggota keluarga memilih untuk tidur di ruang tunggu. Dalam penelitian (Day et al. 2013) terdapat 19. 1\% responden yang memilih untuk bermalam di ruang tunggu karena terlalu cemas untuk jauh dari pasien.

Kesulitan tidur adalah masalah kesehatan lazim terjadi pada anggota keluarga pasien yang di rawat di rumah sakit. Ada banyak faktor yang menyebabkan kurang tidur pada anggota keluarga pasien yangdi rawat. Pada 
penelitian ini anggota keluarga melaporkan bahwa kecemasan, ketegangan, dan ketakutan merupakan tiga alasan paling umum dalam gangguan tidur atau kurang tidur. Stimulan emosional, seperti kecemasan, ketakutan, dan ketegangan, telah terbukti berdampak negatif pada kemampuan seseorang untuk tertidur . 43,6\% anggota keluarga melaporkan kecemasan sebagai penyebab gangguan tidur (Day et al. 2013).

Selain keadaan psikologis keluarga, lokasi tempat istirahat keluarga di ruang rawat inap pun menjadi hal yang menyebabkan anggota keluarga/pendamping mengalami gangguan tidur. Hasil penelitian kami menunjukkan bahwa lokasi anggota keluarga tidur merupakan faktor utama gangguan tidur. Responden yang menghabiskan satu malam atau lebih tidur di rumah sakit mengalami gangguan tidur lebih banyak dibandingkan mereka yang tidak tidur malam di rumah sakit. Berdasarkan hasil wawancara pada penelitian (Nur et al. 2020) ditemukan informasi bahwa keluarga pasien merasakan ketidaknyamanan saat beristirahat karena tidak adanya tempat private yang tertutup untuk keluarga pasien beristirahat terutama pada malam hari. Keluarga pasien tidur dan beristirahat di lantai koridor rumah sakit atau bahkan di bawah tempat tidur pasien, dengan keadaan yang dingin, pencahayaan yang tidak sesuai, bantalan tempat tidur yang tidak cukup nyaman untuk beristirahat. Gangguan-gangguan tidur tersebutlah yang membuat keluarga mengalami kualitas tidur yang buruk.

Dampak dari kualitas tidur yang buruk pada keluarga pasien diantaranya adalah mereka akan mengalami kesulitan dalam mengambil keputusan, konsentrasi yang buruk, kualitas hidup yang buruk, keadaan emosi yang tinggi, gangguan ingatan dalam menerima informasi, dan dapat mempengaruhi kemampuan keluarga untuk mencari nafkah (Day et al. 20/3) . Selain itu kualitas tidur yang buruk pada malam hari terhadap keluarga pasien dapat menyebabkan perasaan kantuk berlebih saat siang hari. Penelitian Verceles et al., (2014) mendapatkan hasil bahwa 50,2\% anggota keluarga pasien mengalami kantuk di siang hari yang berlebihan. Mereka yang mengantuk mengalami gangguan yang lebih besar dalam melakukan aktivitas sehari-hari.

Berdasarkan analisa peneliti, kualitas tidur yang buruk yang dialami keluarga pasien diruang rawat inap Rumah Sakit Izza Cikampek Di Masa Pandemic Covid-19 disebabkan karena perasaan psikologis yang dirasakan keluarga dan kondisi tempat istirahat keluarga saat di ruang rawat inap. Keadaan khawatir, cemas, tegang melihat keadaan pasien ternayata dapat membuat pendamping merasa tidak tenang saat ingin beristirahat atau sekedar meninggalkan pasien. Selain itu kondisi tempat istirahat pendamping di ruang rawat inap pun kurang memadai, rumah sakit tidak memfasilitasi ruangistirahat khusus untuk keluarga, sehingga keluarga harus beristirahat di ruang tunggu, dibangku, di bawah tempat tidur pasien, di koridor dll hal tersebut merupakan gangguan-gangguan tidur yang membuat kualitas tidur pasien menjadi tidak baik atau buruk. Keadaan pandemi COVID-I9 saat ini membuat banyak diantara keluarga pasien yang merasa khawatir dan semakin cemas, mereka khawatir dirinya atau pasien terpapar COVID-19 saat di rawat di rumah sakit, sehingga membuat mereka kesulitan untuk tidur karena memikirkan hal tersebut. Selain itu karena adanya pembatasan keluarga yang mendamping pasien di rumah sakit membuat keluarga / pendamping sulit beristirahat, mereka harus berjaga sepanjang hari seorang diri, terutama ketika malam hari, hal tersebut membuat keluarga pasien mengalami kualitas tidur yang buruk.

\section{KESIMPULAN}

Keluarga pasien mayoritas berusia dewasa akhir (36-45 tahun), berjenis kelamin perempuan, pendidikan SMA sederajat, pekerjaan bekerja, status hubungan keluarga inti dan tidak memiliki riwayat penyakit. Prevalensi kualitas tidur keluarga pasien mayoritas berada pada 
kualitas tidur cukup. Pada hasil penelitian ini tidak ada responden yang mengalami kualitas tidur buruk sekali ataupun baik sekali.

\section{REFERENSI}

I. Suastika, Eka, Bagus Jaya, and Busiarsa IGN. 2020. "Prevalensi Kualitas Tidur Pada Pendamping Pasien (Caregiver) Di Ruang Mawar RSUP Sanglah." Medicina 5I(I):50-53. doi: I0.I5562/medicina.v5lil.75I.

2. Nur'aini, Nur'aini, Sri Sofyani, Supriatmo Supriatmo, and Iskandar Z. Lubis. 2014. "Comparing Sleep Disorders in Urban and Suburban Adolescents." Paediatrica Indonesiana 54(5):299. doi: 10.14238/pi54.5.2014.299-304.

3. World Health Organization. 2021. "WHO COVID-19 Global Table Data December Ist 2020 at II." WHO Coronavirus Disease.

4. Suastika Anak Agung, Eka, Bagus Jaya Lesmana Cokorda, and Budiarsa IGN. 2020. "Prevalensi Kualitas Tidur Pada Pendamping Pasien (Caregiver) Di Ruang Mawar RSUP Sanglah." Medicina 5I(I):50-53. doi: I0.I5562/medicina.v5lil.75I.

5. Robert L, Owens, Troung-Giang Huynh, and Netzer Giora. 2017. "Tidur Di Unit Perawatan Intensif Dalam Model.” 28(2): I7I-79.

6. Schmidt, Matthieu, and Elie Azoulay. 20I3. "Malam Tanpa Tidur Di ICU : Keluarga Yang Terbangun.” I7(1003): I-2.

7. Amzal Mortin Andas, Christantie Effendi, and Sri Setyarini. 2020. "Validity and Reliability Test on Sleep Quality Scale (SQS) Instruments in Indonesia Version on Cancer Patients." International Journal of Research in Pharmaceutical Sciences II (4):7275-80. doi: I0.26452/ijrps.v I li4.3865.

8. Cappelleri, Joseph C., Andrew G. Bushmakin, Anne Mmcdermott, Alesia B. Sadosky, and Charles D. Petrie. 2009. "Kesehatan Dan Hasil Kualitas Hidup Dengan Fibromyalgia." Bio Med Pusat 7:1-7.

9. Verceles, Avelino C., Douglas S. Corwin, Majid Afshar, Eliot B. Friedman, Michael T. McCurdy, Carl Shanholtz, Karen Oakjones, Marc T. Zubrow, Jennifer Titus, and Giora Netzer. 2014. "Half of the Family Members of Critically III Patients
Experience Excessive Daytime Sleepiness." Intensive Care Medicine 40(8):|I24-3|. doi: I0.1007/s00 |34-0|4-3347-z.

10. Khasanah, Khusnul, and Wahyu Hidayati. 2012. "Kualitas Tidur Lansia Balai Rehabilitasi Sosial 'Mandiri' Semarang.” I:I89-96.

II. Baskara, Ferdyta, and chandra bagus Ropyanto. 2017. "Hubungan Tingkat Kecemasan Dengan Kualitas Tidur Anggota Keluarga Di RSUD K.R.M.T. Wongsonegoro.” I-8.

12. Harfiantoko, Mirza Nursyamsu, and Erlin Kurnia. 2013. "Derajat Hipertensi (Menurut WHO) Mempengaruhi Kualitas Tidur Dan Stress Psikososial." Jurnal Stikes 6(2):I-12.

13. Day, Alex, Samer Haj-Bakri, Stephanie Lubchansky, and Sangeeta Mehta. 2013. "Sleep, Anxiety and Fatigue in Family Members of Patients Admitted to the Intensive Care Unit: A Questionnaire Study." Critical Care 17(3). doi: I0.1 |86/cc|2736.

14. Halm, Margo A., Marita G. Titler, Charmaine Kleiber, Susan K. Johnson, Lou Ann Montgomery, Martha J. Craft, Kaihleen Buckwalter, Anita Nicholson, and Karen Megern. 1993. "Behavioral Responses of Family Members during Critical Illness." Clinical Nursing Research 2(4):4 |4-37.

15. Nur, Safriana, Awaliah Akbar, Aep Rusmana, Politeknik Kesejahteraan, Sosial Bandung, Moch Zaenal Hakim, Politeknik Kesejahteraan, and Sosial Bandung. 2020. "BURNOUT PADA KELUARGA PASIEN DI RUANG PEDIATRIC INTENSIVE CARE UNIT ( PICU ) RSUD ULIN BANJARMASIN.” 2(2):9I-I05.

16. Van Horn, Elizabeth, and Anita Tesh. 2000. "The Effect of Critical Care Hospitalization on Family Members: Stress and Responses." Dimensions of Critical Care Nursing 19(4):40-49. 